\title{
Influence of Culture Media and Explants on in vitro Regeneration Efficiency of Elite Guava Cultivars
}

\author{
Sunita Devi ${ }^{1^{*}}$ and Neelam R. Yadav ${ }^{2}$ \\ ${ }^{1}$ Division of Crop Improvement, ICAR - Central Soil Salinity Research Institute, \\ Karnal, Haryana, India \\ ${ }^{2}$ CCS Haryana Agricultural University, Hisar, India \\ *Corresponding author
}

\section{A B S T R A C T}

\section{Keywords}

Guava,

Regeneration

efficiency,

Explants, Media,

Growth regulators

Article Info

Accepted:

17 January 2021

Available Online:

10 February 2021
Guava which is multinutritive or multifunctional fruit is largely consumed by people. So, there has been substantial interest in the mass production and advancement of elite guava planting materials. Different medium components with variable concentration of plant growth regulators significantly affect regeneration ability either through nodal or shoot tip explants. Recent reports developed the standard protocol using different types of basal medium (MS and WPM) with variable concentration and combination of plant growth regulators for four elite cultivars of guava. Out of variable combination of regulators BAP with either with NAA, IAA and Kinetin showed higher regeneration efficiency. The study showed that four cultivars exhibited high frequency of regeneration that is $115.51 \%$ in Hisar Safeda, $110.06 \%$ in Hisar Surkha, 175.52\% in Lucknow-49 and $125.92 \%$ in Allahabad Safeda in nodal explants with WPM medium. Whereas in case of shoot tip explants higher percent was $95.34 \%$ in Hisar Safeda, 70.95\% in Hisar Surkha, $133.21 \%$ in Lucknow and $152.18 \%$ in Allahabad Safeda recorded. In the regeneration study, it was observed that combination of BAP $(2.5 \mathrm{mg} / \mathrm{l})$, Kinetin $(1.0 \mathrm{mg} / \mathrm{l})$ and NAA $(0.2 \mathrm{mg} / \mathrm{l})$ with WPM has potential to promote higher regeneration of cultivar Lucknow-49 and Allahabad Safeda. Whereas BAP (2.5 mg/l) with NAA (0.2 mg/l) in Hisar Safeda and BAP (2.5 mg/l) with IAA $(0.5 \mathrm{mg} / \mathrm{l})$ in Hisar Surkha showed higher regeneration for both explants. The optimized protocol will be helpful for cultivars specific mass production through in vitro culture.

\section{Introduction}

Psidium guajava (L.) is an evergreen tropical and subtropical fruit tree of Myrtaceae family which is native to tropical America (Peru) (Rawls et al., 2015). Due to its wider adaptability in various types of soil, $\mathrm{pH}$, drought and frost, it is also well known as
"Apple of tropic". Guava is well characterized by its nutritional and abundant pharmaceutical active components which gives higher economical benefits to farmer as it produces fruits twice in a year (winter and summer seasons), that makes it as a favorable cash crop instead of other cereal crops. Biochemical profiling of guava fruit has 
shown that they are rich in vitamin $\mathrm{C}$ (100$250 \mathrm{mg} / 100$ of pulp) as well as a good source of calcium, phosphorous, iron, pectin and antioxidants such as lycopene, carotenoids and polyphenols (Liu and Yang, 2011). Every part of guava tree like leaves, bark and fruits are used to treat diarrhea and other stomach problem (Kamle et al., 2013). India and Mexico is leading producer of guava (Usman et al., 2012) and in 2019, guava production was 3.345 million tonnes (NHB, 2017-18). Guava can be propagated by vegetative methods like shoot cutting, grafting, air layering though these methods are not suitable for producing large numbers of planting materials as these are tedious, laborious, time taking with limited plants production (Bisen et al., 2014; Singh et al., 2015; Rajkumar et al., 2016; Mousa et al., 2017). It shortens the supply of planting material to overcome growing demand of farmers. So plant biotechnological techniques like micropropagation is one of solution for all constrains of vegetative methods. Plant tissue culture is an adjunct to conventional breeding methods (Meghwal et al., 2010). It is only viable alternative for producing abundant plants which are uniform or true to type, disease free, highly productive and germplasm conservation (Rai et al., 2012). In another way, in vitro method is independent to environment, rapid and cost-effective for large scale-propagation of elite cultivars of guava. Various attempts have been made for micropropagation of guava using direct and indirect organogenesis in Allahabad Safeda, Lucnow-49 and other cultivars (Kamle et al., 2013), but some constraints like browning and fungal contamination persists in clonal propagation of guava. So present investigation was carried out to check the regeneration efficiency of different explants and develop highly reproducible micropropagation protocol for commercial production of guava plants.

\section{Materials and Methods}

Terminal shoot tips and nodal explants (2-3 $\mathrm{cm}$ ) of four cultivars (Cultivars Lucknow-49, Allahabad Safeda, Hisar Safeda and Hisar Surkha) were collected from 5-7 year old mother plants from Farm Area, CCS HAU Hisar. To avoid exudation of phenolic substances, newly sprouted twigs were collected in $100 \mathrm{ml}$ dilute solution of citric acid $(75 \mathrm{mg} / \mathrm{l})$, ascorbic acid $(50 \mathrm{mg} / \mathrm{l})$ with 2 3 drops of tween-20 (polyoxy ethylene sorbitan monolaurate). Surface sterilization of nodal as well as shoot tip explants $(1.0-1.5$ $\mathrm{cm})$ were done properly before inoculated on culture medium properly washed with running tap water for half an hour. MS (Murashige and Skoog) and WPM (Woody plant medium) medium fortified with various combination of different plant growth regulators like BAP, kinetin, NAA and IAA. For each type of media, 30 explants in three replicates were used. Cultures were then transferred to optimum conditions of temperature $\left(26 \pm 2^{\circ} \mathrm{C}\right)$, light (4000 Lux) and photoperiod cycle (16 hours light and 8 hours dark). Well sterile and established cultures were sub-cultured on similar medium for further multiplication. Regeneration efficiency of nodal and shoot tip explants was calculated separately as percent shoot induction x Mean no. of shoots/explant cultured on MS and WPM media in four cultivars of guava. Each media treatment was repeated three times with 30 explants per replicate giving a total of 90 explants per treatment for single cultivar and observations were recorded weekly. The data collected was analyzed statically using block design (Version 9.3, SAS Institute Inc., Cary, NC, USA) and mean differences were compared at 5 per cent probability using Tukey's test.

\section{Results and Discussion}

Any part of the plants could be used as an explant source, but the type of explant has a 
prime importance in their response to tissue culture for initiation, growth and regeneration potential (Kumar et al., 2014) as well as the composition of culture medium is also an important factor for successful establishment of tissue culture plantlets (Zhang et al., 2020). In the present study, percent regeneration efficiency was calculated as percent shoot induction $\mathrm{x}$ mean no. of shoots/explants, which mainly depends on different media combinations. The regeneration efficiency was calculated separately in nodal and shoot tip explants cultured on MS and WPM media in four cultivars of guava.

\section{Regeneration efficiency on MS media}

All the studied cultivars showed variable response for regeneration efficiency using nodal and shoot tip explants (Table 1). In Hisar Safeda, maximum regeneration efficiency (68.84\%) was obtained in MS with $2.5 \mathrm{mg} / \mathrm{l} \mathrm{BAP}$ and $0.2 \mathrm{mg} / \mathrm{l} \mathrm{NAA}$ through nodal explants (Table 1) while shoot tip explants cultured on MS medium supplemented with $2.5 \mathrm{mg} / \mathrm{l}$ BAP, $1.0 \mathrm{mg} / \mathrm{l}$ Kinetin and $0.2 \mathrm{mg} / \mathrm{l}$ NAA showed highest regeneration efficiency $(58.52 \%)$. Lowest regeneration efficiency of $3.35 \%$ and $5.40 \%$ was observed in nodal explants and shoot tip explants cultured on MS medium fortified with $1.5 \mathrm{mg} / \mathrm{l} \mathrm{TDZ}$ and $0.2 \mathrm{mg} / \mathrm{l} \mathrm{NAA}$. Similar to Hisar Safeda, Hisar Surkha also showed maximum regeneration efficiency of $94.62 \%$ and $58.55 \%$ in MS medium with 2.5 $\mathrm{mg} / \mathrm{l} \mathrm{BAP}$ and $0.2 \mathrm{mg} / \mathrm{l}$ NAA using nodal explants and shoot tip explants, respectively (Table 1). Lowest regeneration efficiency of $4.28 \%$ in nodal explants and $4.85 \%$ in shoot tip explants was observed on MS medium fortified with $1.5 \mathrm{mg} / \mathrm{l} \mathrm{TDZ}$ (Table 1). In case of nodal explants, Lucknow-49 and Allahabad Safeda showed maximum regeneration efficiency of $137.42 \%$ and $115.88 \%$ on MS medium fortified with $2.5 \mathrm{mg} / \mathrm{l} \mathrm{BAP}, 1.0 \mathrm{mg} / \mathrm{l}$ Kinetin and $0.2 \mathrm{mg} / \mathrm{l}$ NAA (Table 1). Lowest regeneration efficiency of $3.36 \%$ in Lucknow49 was observed on MS with $1.5 \mathrm{mg} / \mathrm{l} \mathrm{TDZ}$, $0.2 \mathrm{mg} / \mathrm{l}$ NAA while $3.97 \%$ in Allahabad Safeda on MS medium fortified with $1.5 \mathrm{mg} / \mathrm{l}$ TDZ only (Table 1). Similarly, shoot tip explants cultured on MS medium supplemented with $2.5 \mathrm{mg} / \mathrm{l}$ BAP, $1.0 \mathrm{mg} / \mathrm{l}$ Kinetin and $0.2 \mathrm{mg} / \mathrm{l}$ NAA also showed higher regeneration efficiency of $93.25 \%$ in Lucknow-49 while in Allahabad Safeda, MS medium containing $2.5 \mathrm{mg} / \mathrm{l} \mathrm{BAP}$ and 0.2 mg/l NAA showed maximum regeneration efficiency $(63.19 \%)$. MS medium consisted of $1.5 \mathrm{mg} / \mathrm{l}$ TDZ had lowest regeneration efficiency for Lucknow-49 (4.85\%) and MS medium with $1.5 \mathrm{mg} / \mathrm{l} \mathrm{TDZ}$ and $0.5 \mathrm{mg} / \mathrm{l} \mathrm{IAA}$ showed lower regeneration efficiency of $5.37 \%$ in Allahabad Safeda (Table 1). Direct shoot proliferation was found to be dependent on synergistic effect of cytokinins along with auxin in the medium which evoked good results for shoot proliferation (Kumar et al., 2013). The maximum shoot proliferation and number of shoots was formed directly from node explants due to the presence of preexisting axillary primordia which proliferated into shoots under adequate amount of cytokinin along with small amount of auxins supplied in nutrient medium which nullified the effect of apical dominance and thus enhanced the proliferation of axillary buds (Kumar et al., 2017).

In comparison with MS, there was highest regeneration efficiency was obtained with WPM medium with various combinations of plant growth regulators. A detail of all such combinations and their responses are depicted in Table 2. In case of nodal explants higher regeneration efficiency (115.51\%) was observed with combination of Woody plant medium (Figure 1), $2.5 \mathrm{mg} / \mathrm{l} \mathrm{BAP}$ and 0.5 mg/l IAA but in case of shoot tip explants (Figure 2) higher regeneration (95.34\%) was obtained with $2.5 \mathrm{mg} / \mathrm{l} \mathrm{BAP}$ and $0.5 \mathrm{mg} / \mathrm{l} \mathrm{IAA}$ in cultivar Hisar Safeda. 
Table.1 Regeneration efficiency (\%) in cultured nodal and shoot tip explants of four guava cultivars on MS media

\begin{tabular}{|c|c|c|c|c|c|c|c|c|c|}
\hline \multirow[t]{2}{*}{$\begin{array}{l}\text { S. } \\
\text { No. }\end{array}$} & \multirow[t]{2}{*}{$\begin{array}{l}\text { MS media + growth regulators } \\
(\mathrm{mg} / \mathrm{l})\end{array}$} & \multicolumn{4}{|c|}{$\begin{array}{c}\text { Regeneration efficiency }(\%) \text { of nodal } \\
\text { explants }\end{array}$} & \multicolumn{4}{|c|}{$\begin{array}{c}\text { Regeneration efficiency }(\%) \text { of shoot } \\
\text { tip explants }\end{array}$} \\
\hline & & $\begin{array}{c}\text { Hisar } \\
\text { Safeda }\end{array}$ & $\begin{array}{l}\text { Hisar } \\
\text { Surkha }\end{array}$ & $\begin{array}{l}\text { Lucknow } \\
49\end{array}$ & $\begin{array}{c}\text { Allahabad } \\
\text { Safeda }\end{array}$ & $\begin{array}{c}\text { Hisar } \\
\text { Safeda }\end{array}$ & $\begin{array}{l}\text { Hisar } \\
\text { Surkha }\end{array}$ & $\begin{array}{c}\text { Lucknow } \\
49\end{array}$ & $\begin{array}{l}\text { Allahabad } \\
\text { Safeda }\end{array}$ \\
\hline 1 & $1.5 \mathrm{TDZ}$ & $6.79^{\mathrm{D}}$ & $4.28^{\mathrm{F}}$ & $5.23^{\mathrm{GH}}$ & $3.97^{\mathrm{E}}$ & $9.24^{\mathrm{D}}$ & $4.85^{\mathrm{E}}$ & $6.26^{\mathrm{E}}$ & $5.76^{\mathrm{D}}$ \\
\hline 2 & $1.5 \mathrm{TDZ}+0.2 \mathrm{NAA}$ & $3.35^{\mathrm{D}}$ & $4.45^{\mathrm{F}}$ & $3.36^{\mathrm{H}}$ & $4.03^{\mathrm{E}}$ & $5.40^{\mathrm{D}}$ & $6.71^{\mathrm{E}}$ & $6.56^{\mathrm{E}}$ & $7.49^{\mathrm{D}}$ \\
\hline 3 & $1.5 \mathrm{TDZ}+0.5 \mathrm{IAA}$ & $3.41^{\mathrm{D}}$ & $4.78^{\mathrm{F}}$ & $6.38^{\mathrm{FGH}}$ & $4.77^{\mathrm{E}}$ & $7.24^{\mathrm{D}}$ & $6.03^{\mathrm{E}}$ & $4.90^{\mathrm{E}}$ & $5.37^{\mathrm{D}}$ \\
\hline 4 & $2.5 \mathrm{BAP}$ & $46.80^{\mathrm{B}}$ & $29.73^{\mathrm{DE}}$ & $54.95^{\mathrm{CDE}}$ & $30.34^{\mathrm{CD}}$ & $47.14^{\mathrm{B}}$ & $32.69^{\mathrm{CD}}$ & $68.91^{\mathrm{B}}$ & $29.25^{\mathrm{C}}$ \\
\hline 5 & $2.5 \mathrm{BAP}+0.2 \mathrm{NAA}$ & $68.84^{\mathrm{A}}$ & $94.62^{\mathrm{A}}$ & $101.62^{\mathrm{B}}$ & $53.44^{\mathrm{B}}$ & $55.97^{\mathrm{AB}}$ & $58.55^{\mathrm{A}}$ & $76.12^{\mathrm{AB}}$ & $66.43^{\mathrm{A}}$ \\
\hline 6 & $2.5 \mathrm{BAP}+0.5 \mathrm{IAA}$ & $52.44^{\mathrm{B}}$ & $34.21^{\mathrm{CD}}$ & $74.38^{\mathrm{CD}}$ & $46.93^{\mathrm{B}}$ & $56.54^{\mathrm{AB}}$ & $33.18^{\mathrm{C}}$ & $47.01^{\mathrm{CD}}$ & $35.24^{\mathrm{C}}$ \\
\hline 7 & 1.0 Kinetin & $27.62^{\mathrm{C}}$ & $22.48^{\mathrm{E}}$ & $32.61^{\mathrm{EF}}$ & $33.77^{\mathrm{C}}$ & $28.71^{\mathrm{C}}$ & $20.69^{\mathrm{D}}$ & $40.16^{\mathrm{CD}}$ & $35.65^{\mathrm{C}}$ \\
\hline 8 & 1.0 Kinetin $+0.2 \mathrm{NAA}$ & $26.75^{\mathrm{C}}$ & $33.79^{\mathrm{CDE}}$ & $48.78^{\mathrm{DE}}$ & $23.74^{\mathrm{D}}$ & $29.08^{\mathrm{C}}$ & $31.48^{\mathrm{CD}}$ & $31.23^{\mathrm{D}}$ & $30.92^{\mathrm{C}}$ \\
\hline 9 & 1.0 Kinetin + 0.5 IAA & $31.54^{\mathrm{C}}$ & $36.08^{\mathrm{CD}}$ & $30.72^{\mathrm{EFG}}$ & $29.00^{\mathrm{CD}}$ & $29.71^{\mathrm{C}}$ & $33.07^{\mathrm{C}}$ & $36.72^{\mathrm{CD}}$ & $27.58^{\mathrm{C}}$ \\
\hline 10 & 2.5 BAP +1.0 Kinetin $+0.2 \mathrm{NAA}$ & $54.71^{\mathrm{B}}$ & $47.89^{\mathrm{B}}$ & $137.42^{\mathrm{A}}$ & $115.88^{\mathrm{A}}$ & $66.74^{\mathrm{A}}$ & $57.34^{\mathrm{AB}}$ & $93.25^{\mathrm{A}}$ & $53.69^{\mathrm{B}}$ \\
\hline 11 & $2.5 \mathrm{BAP}+1.0$ Kinetin $+0.5 \mathrm{IAA}$ & $49.21^{\mathrm{B}}$ & $41.76^{\mathrm{BC}}$ & $77.02^{\mathrm{BC}}$ & $48.36^{\mathrm{B}}$ & $58.52^{\mathrm{AB}}$ & $46.04^{\mathrm{B}}$ & $56.53^{\mathrm{BC}}$ & $63.19^{\mathrm{AB}}$ \\
\hline & General mean & 33.77 & 32.19 & 52.04 & 35.84 & 35.85 & 30.06 & 42.52 & 32.78 \\
\hline & Tukey HSD at $5 \%$ & 8.46 & 13.19 & 11.52 & 27.15 & 11.47 & 12.32 & 20.5 & 11.95 \\
\hline
\end{tabular}


Table.2 Regeneration efficiency (\%) in cultured nodal and shoot tip explants of four guava cultivars on WPM media

\begin{tabular}{|c|c|c|c|c|c|c|c|c|c|}
\hline \multirow[t]{2}{*}{$\begin{array}{l}\text { S. } \\
\text { No. }\end{array}$} & \multirow[t]{2}{*}{$\begin{array}{l}\text { WPM media + growth regulators } \\
\qquad(\mathrm{mg} / \mathrm{l})\end{array}$} & \multicolumn{4}{|c|}{ Regeneration efficiency (\%) of nodal explants } & \multicolumn{4}{|c|}{$\begin{array}{c}\text { Regeneration efficiency }(\%) \text { of shoot tip } \\
\text { explants }\end{array}$} \\
\hline & & $\begin{array}{l}\text { Hisar } \\
\text { Safeda }\end{array}$ & $\begin{array}{l}\text { Hisar } \\
\text { Surkha }\end{array}$ & $\begin{array}{l}\text { Lucknow } \\
\quad 49\end{array}$ & $\begin{array}{l}\text { Allahabad } \\
\text { Safeda }\end{array}$ & $\begin{array}{l}\text { Hisar } \\
\text { Safeda }\end{array}$ & $\begin{array}{l}\text { Hisar } \\
\text { Surkha }\end{array}$ & $\begin{array}{l}\text { Lucknow } \\
\quad 49\end{array}$ & $\begin{array}{l}\text { Allahabad } \\
\text { Safeda }\end{array}$ \\
\hline 1 & $1.5 \mathrm{TDZ}$ & $5.43^{\mathrm{E}}$ & $5.74^{\mathrm{F}}$ & $6.44^{\mathrm{E}}$ & $4.79^{\mathrm{E}}$ & $6.27^{\mathrm{E}}$ & $4.53^{\mathrm{D}}$ & $5.32^{\mathrm{E}}$ & $4.75^{\mathrm{D}}$ \\
\hline 2 & $1.5 \mathrm{TDZ}+0.2 \mathrm{NAA}$ & $3.99^{\mathrm{E}}$ & $6.71^{\mathrm{EF}}$ & $4.79^{\mathrm{E}}$ & $4.98^{\mathrm{E}}$ & $5.43^{\mathrm{E}}$ & $5.59^{\mathrm{CD}}$ & $6.53^{\mathrm{E}}$ & $7.56^{\mathrm{D}}$ \\
\hline 3 & $1.5 \mathrm{TDZ}+0.5 \mathrm{IAA}$ & $5.55^{\mathrm{E}}$ & $5.19^{\mathrm{F}}$ & $4.72^{\mathrm{E}}$ & $5.23^{\mathrm{E}}$ & $5.41^{\mathrm{E}}$ & $6.49^{\mathrm{CD}}$ & $4.20^{\mathrm{E}}$ & $5.49^{\mathrm{D}}$ \\
\hline 4 & $2.5 \mathrm{BAP}$ & $90.82^{\mathrm{B}}$ & $39.19^{\mathrm{CD}}$ & $105.31^{\mathrm{BC}}$ & $34.98^{\mathrm{D}}$ & $79.53^{\mathrm{B}}$ & $30.12^{\mathrm{B}}$ & $45.27^{\mathrm{BCD}}$ & $33.73^{\mathrm{C}}$ \\
\hline 5 & $2.5 \mathrm{BAP}+0.2 \mathrm{NAA}$ & $70.12^{\mathrm{C}}$ & $110.06^{\mathrm{A}}$ & $120.29^{\mathrm{B}}$ & $90.65^{\mathrm{B}}$ & $68.85^{\mathrm{C}}$ & $70.95^{\mathrm{A}}$ & $55.84^{\mathrm{B}}$ & $81.56^{\mathrm{B}}$ \\
\hline 6 & $2.5 \mathrm{BAP}+0.5 \mathrm{IAA}$ & $115.51^{\mathrm{A}}$ & $43.54^{\mathrm{C}}$ & $84.22^{\mathrm{C}}$ & $55.82^{\mathrm{C}}$ & $95.34^{\mathrm{A}}$ & $37.84^{\mathrm{B}}$ & $29.94^{\mathrm{D}}$ & $40.42^{\mathrm{C}}$ \\
\hline 7 & 1.0 Kinetin & $31.55^{\mathrm{D}}$ & $22.97^{\mathrm{DE}}$ & $47.78^{\mathrm{D}}$ & $36.75^{\mathrm{D}}$ & $33.67^{\mathrm{D}}$ & $21.74^{\mathrm{BC}}$ & $37.09^{\mathrm{CD}}$ & $37.38^{\mathrm{C}}$ \\
\hline 8 & 1.0 Kinetin $+0.2 \mathrm{NAA}$ & $27.17^{\mathrm{D}}$ & $35.98^{\mathrm{CD}}$ & $46.32^{\mathrm{D}}$ & $33.34^{\mathrm{D}}$ & $32.67^{\mathrm{D}}$ & $30.46^{\mathrm{B}}$ & $29.12^{\mathrm{D}}$ & $32.31^{\mathrm{C}}$ \\
\hline 9 & 1.0 Kinetin +0.5 IAA & $28.77^{\mathrm{D}}$ & $38.57^{\mathrm{CD}}$ & $44.00^{\mathrm{D}}$ & $34.98^{\mathrm{D}}$ & $25.57^{\mathrm{D}}$ & $27.19^{\mathrm{B}}$ & $30.03^{\mathrm{D}}$ & $30.62^{\mathrm{C}}$ \\
\hline 10 & $2.5 \mathrm{BAP}+1.0$ Kinetin $+0.2 \mathrm{NAA}$ & $83.85^{\mathrm{BC}}$ & $62.22^{\mathrm{B}}$ & $175.52^{\mathrm{A}}$ & $125.92^{\mathrm{A}}$ & $74.23^{\mathrm{BC}}$ & $56.80^{\mathrm{A}}$ & $133.21^{\mathrm{A}}$ & $152.18^{\mathrm{A}}$ \\
\hline 11 & $2.5 \mathrm{BAP}+1.0$ Kinetin + 0.5 IAA & $85.28^{\mathrm{BC}}$ & $45.50^{\mathrm{C}}$ & $51.10^{\mathrm{D}}$ & $91.06^{\mathrm{B}}$ & $77.74^{\mathrm{BC}}$ & $32.40^{\mathrm{B}}$ & $47.02^{\mathrm{BC}}$ & $69.08^{\mathrm{B}}$ \\
\hline \multicolumn{2}{|c|}{ General Mean } & 49.82 & 37.79 & 62.77 & 47.14 & 45.88 & 29.47 & 38.51 & 45.01 \\
\hline \multicolumn{2}{|c|}{ Tukey HSD at 5\% } & 19.5 & 16.71 & 21.72 & 18.61 & 10.46 & 16.77 & 16.76 & 17.76 \\
\hline
\end{tabular}


Fig.1 Multiple shoot induction in guava cv. from nodal explants

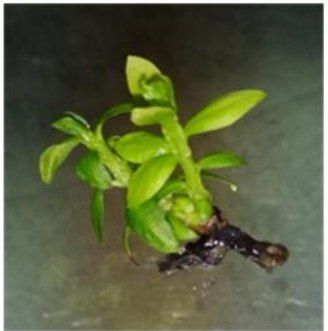

Lucknow - 49

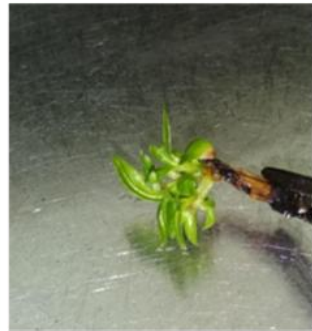

Allahabad Safeda

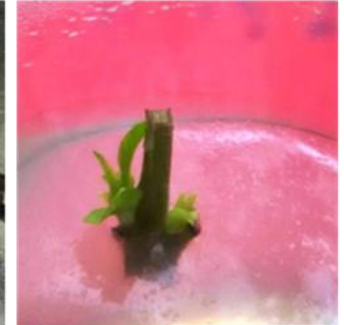

Hisar Surkha

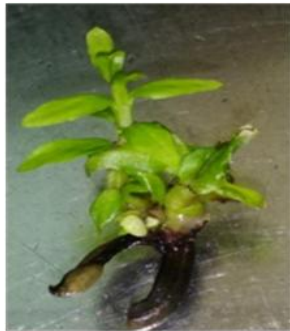

Hisar Safeda

Fig.2 Multiple shoot induction in guava cv. from shoot tip explants

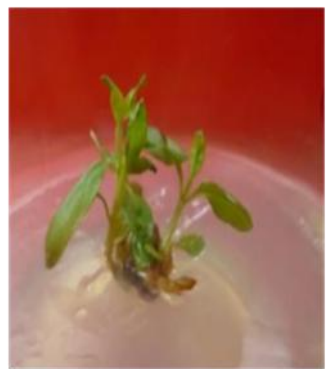

Lucknow - 49

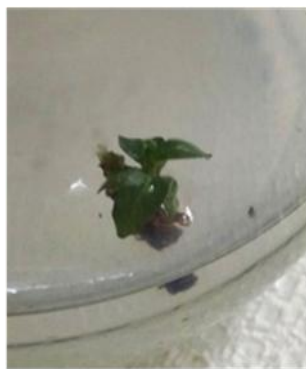

Allahabad Safeda

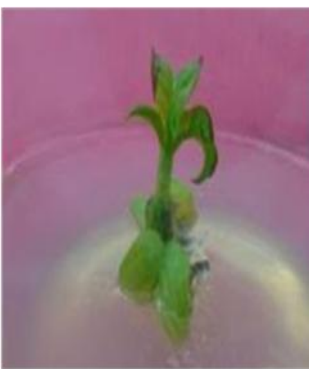

Hisar Surkha

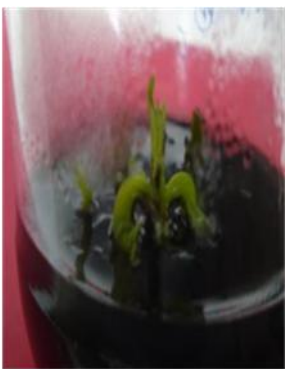

Hisar Safeda
In Hisar Surkha, both nodal and shoot tip explants showed maximum regeneration efficiency of $110.06 \%$ and $70.95 \%$ respectively on WPM medium (WBN) with $2.5 \mathrm{mg} / \mathrm{l}$ BAP and $0.2 \mathrm{mg} / \mathrm{l}$ NAA. In Luckhnow-49 nodal with $175.52 \%$ and shoot tip with $133.21 \%$ whereas in case of Allahabad Safeda nodal and shoot tip regeneration efficiency $125.92 \%$ and $152.18 \%$ was obtained when cultured on WPM medium fortified with $2.5 \mathrm{mg} / \mathrm{l} \mathrm{BAP}$, $1.0 \mathrm{mg} / \mathrm{l} \mathrm{Kinetin}$ and $0.2 \mathrm{mg} / \mathrm{l} \mathrm{NAA}$ which is similar media for both cultivars. Minimum response $3.99 \%$ in nodal explant with WPM consisting $1.5 \mathrm{mg} / \mathrm{l} \mathrm{TDZ}$ and $0.2 \mathrm{mg} / \mathrm{l} \mathrm{NAA} 1$ and $5.41 \%$ in shoot tip explants with WPM medium consisted of $1.5 \mathrm{mg} / \mathrm{l} \mathrm{TDZ}$ and 0.5 mg/l IAA) was obtained in Hisar Safeda. In cultivar Hisar Surkha, lowest regeneration efficiency $(4.53 \%)$ was recorded when shoot tip explants were cultured on WPM medium consisted of $1.5 \mathrm{mg} / \mathrm{l} \mathrm{TDZ}$ and in nodal explants minimum efficiency of $4.53 \%$ was observed on WPM medium with $1.5 \mathrm{mg} / \mathrm{l}$
TDZ and $0.5 \mathrm{mg} / \mathrm{l}$ IAA. In case of nodal explants Lowest regeneration efficiency (4.72\%) on WPM medium (WTI) with 1.5 $\mathrm{mg} / \mathrm{l} \mathrm{TDZ}, 0.5 \mathrm{mg} / \mathrm{l} \mathrm{IAA}$ in Luckhnow-49 and $4.79 \%$ in Allahabad Safeda on WPM basal medium (WT) fortified with $1.5 \mathrm{mg} / \mathrm{l} \mathrm{TDZ}$ was recorded. But lower regeneration efficiency $(4.20 \%)$ in Lucknow-49 was recorded when shoot tip explants were cultured on WPM medium (WTI) supplemented with $1.5 \mathrm{mg} / \mathrm{l} \mathrm{TDZ}$ and 0.5 mg/l IAA. Similarly, lowest regeneration efficiency $(4.75 \%)$ was observed in Allahabad Safeda when shoot tip explants were cultured on WPM medium (WT) consisting of 1.5 $\mathrm{mg} / \mathrm{l} \mathrm{TDZ}$ only. In the earlier reports, it was found that shoot bud induction and plant regeneration was depends on genotypic variations and medium composition and in guava cultivars (Beaumont, Ka Hua Kula and Lucknow-49), Joshee et al., (2004) reported the same results. Our results suggested that explants either node or shoot tip, regeneration efficiency mainly depends on the growth 
regulator interactions and cytokinin to auxin ratio (Zhang et al., 2020).

From the results, it was concluded that cultivar Lucknow-49 was most responsive than other cultivars and nodal explants responded better than the shoot tip explants of guava. Maximum percent regeneration efficiency of $175.17 \%$ was also observed in nodal explants of Lucknow-49 on WPM basal medium with $2.5 \mathrm{mg} / \mathrm{l} \mathrm{BAP,} 1.0 \mathrm{mg} / \mathrm{l}$ kinetin and $0.2 \mathrm{mg} / \mathrm{l}$ NAA. Other cultivars showed per cent regeneration efficiency of 109.77 $125.49 \%$ range in nodal and $70.88-151.94 \%$ in shoot tip explants on fortified WPM medium. WPM basal medium was better effective than MS basal medium for regeneration in guava.

\section{Acknowledgement}

The authors thank Head, Department of molecular Biology, Biotechnology and Bioinformatics, CCS HAU, Hisar for providing the necessary facilities for conducting this experiment.

\section{References}

Bisen, B., Bisen, R. and Singh,Y: Micropropagation of guava (Psidium spp.) A review. Plant Archives., 14(2): 629-635 (2014).

Kamle, M., Kumar, P., Bajpai, A. and Chandra, R: Assessment of genetic fidelity of somatic embryogenesis regenerated guava (Psidium guajava $\mathrm{L}$.) plants using DNA-based markers. New Zealand Journal of Crop and Horticultural Science., DOI:10.1080/01140671.2013.814574 (2013).

Kumar, A., Singh. M and Goyal S.C: Rapid and efficient regeneration protocol in Dioscorea alata L. Vegetos., 26 (02): 191-197 (2013).
Kumar, A., Goyal. S.C., Kajla S and Sharma $\mathrm{N}$ : Rapid protocol for callus induction and differentiation of roots and shoots in Dioscorea alata - a medicinal plant. Indian Journal of Agricultural Sciences., 84 (1): 107-11 (2014).

Kumar, A., Goyal. S.C., Lata. C, Sharma N, Dhansu P and Parshad J: Rapid, Efficient Direct and Indirect Regeneration Protocol of Dioscorea deltoidea wall. National Academy Science Letters., 40(4): 237-240 (2017).

Liu, X. and Yang, G: Clonal propagation of guava (Psidium guajava L) on nodal explants of mature elite cultivars. International Journal of Plant Biology., 2:e2, DOI:10.4081/pb.2011.e2 (2011).

Meghwal, P.R., Sharma, H.C. and Singh S.K: Micropropagation studies on guava. Indian Journal of Biotechnology., 67:55-58 (2010).

Mousa, R.N., Hassan, N.A.F., Stino, R.G. and Gomaa, A.H: Micropropagation of guava (Psidium guajava L.) cv. AlBaladi. Jordan Journal of Agricultural Sciences., 13(1):103-116(2017)

National Horticulture board. (2018), annual report of year 2017-18. http://nhb.gov.in

Rai, M.K., Phulwaria, M., Harish., Gupta, A.K., Shekhawat, N.S. and Jaiswal, U: Genetic homogeneity of guava plants derived from somatic embryogenesis using SSR and ISSR markers. Plant Cell, Tissue and Organ Culture., 111:259-264 (2012).

Rajkumar., Kaur G., Mann A., Lata C., Singh. $\mathrm{A}$ and Kumar A: Biochemical changes in guava (Psidium guajava) cv. Allahabad Safeda fruits as a function of maturity stages. Indian Journal of Agricultural Sciences. 86 (12): 15951600 (2016).

Singh S.P., Mankar A. and Yaseen M: Standardization of micropropagation techniques in guava (Psidium guajava L.). Progressive Horticulture., 47(1) 
DOI:10.5958/2249-

5258.2015.00007.X(2015)

Usman, M., Butt, M. and Fatima, B: Enhanced in vitro multiple shoot induction in elite Pakistani guava cultivars for efficient clonal plant multiplication. African Journal of Biotechnology., $\quad$ 11(44):10182-
19187(2012).

Zhang, Y., Bozorov, T.A., Li, D.X: An efficient in vitro regeneration system from different wild apple (Malus sieversii) explants. Plant Methods., 16:56. https://doi.org/10.1186/s13007020-00599-0 (2020).

\section{How to cite this article:}

Sunita Devi and Neelam R. Yadav. 2021. Influence of Culture Media and Explants on In vitro Regeneration Efficiency of Elite Guava Cultivars. Int.J.Curr.Microbiol.App.Sci. 10(02): 19351942. doi: https://doi.org/10.20546/ijcmas.2021.1002.231 